\title{
Metabolic syndrome in the 1982 Pelotas cohort: effect of contemporary lifestyle and socioeconomic status
}

\author{
Síndrome metabólica na coorte de 1982 da cidade de Pelotas: \\ efeito do estilo de vida contemporâneo e situação socioeconômica
}

Vera Maria Freitas da Silveira ${ }^{1,2}$, Bernardo L. Horta' Denise P. Gigante', Mario Renato Azevedo Junior ${ }^{1}$

1 Programa de Pós-graduação em Epidemiologia, Universidade Federal de Pelotas (UFPel), Pelotas, RS, Brazil

2 Departamento de Clínica Médica, UFPel, Pelotas, RS, Brazil

Correspondence to:

Vera Maria Freitas da Silveira

Rua Félix da Cunha, 614/303

96010-000 - Pelotas, RS, Brazil

veramfs@terra.com.br

Received on Aug/13/2009

Accepted on Mar/1/2010

\begin{abstract}
Objectives: Describe the prevalence of metabolic syndrome, and its association with contemporary lifestyle factors. Subjects and methods: In 2004-2005, 4,296 subjects of the 1982 Pelotas Birth Cohort were evaluated, and metabolic syndrome (MetS) was assessed in 3,599 according to the NCEP-ATP III and IDF criteria. Results: Prevalence of MetS was $5.9 \%$ and $6.7 \%$ for NCEPATPIII and IDF, respectively. Smoking, alcohol intake, and physical activity were not associated with MetS. Among men, the body mass index (BMI) was associated with MetS - overweight [RR: $3.14(95 \% \mathrm{Cl}, 1.97-5.00)]$ and obese subjects [RR: $17.41(95 \% \mathrm{Cl}, 11.85-25.60)]$. In women, family income and schooling were inversely associated with MetS, overweight increased the risk of MetS $7.73(95 \% \mathrm{Cl}, 3.65-16.38)$ times and obesity 40.67 (95\% Cl, 20.85-79.33) times. Conclusions: MetS was more prevalent among men according to NCEP-ATP III criteria, and obesity was the main risk factor. Arq Bras Endocrinol Metab. 2010;54(4):390-7
\end{abstract}

Keywords

Metabolic syndrome; risk factors; birth cohort

\section{RESUMO}

Objetivos: Descrever a prevalência de síndrome metabólica e sua associação com estilo de vida contemporâneo. Sujeitos e métodos: Em 2004-2005, foram avaliados 4.296 participantes da Coorte de nascidos em 1982 de Pelotas, e a presença de síndrome metabólica (MetS) pelos critérios do NCEP-ATP III e da IDF foi pesquisada em 3.599 deles. Resultados: A prevalência de MetS foi de 5,9\% e 6,7\% pelo NCEP-ATP III e IDF, respectivamente. Fumo, ingesta de álcool e atividade física não foram associados com a MetS. Entre os homens, o índice de massa corporal (IMC) foi associado com a MetS - sobrepeso [RR: 3,14 (IC $95 \%$, 1,97-5,00)], e obesos [RR: 17,41 $(95 \%$ IC, $11,85-25,60)]$. Entre as mulheres, a renda familiar e a escolaridade foram associadas inversamente com MetS; o sobrepeso aumentou o risco de MetS 7,73 vezes (IC 95\%, 3,65-16,38) e a obesidade aumentou 40,67 vezes (IC 95\%, 20,85-79,33). Conclusões: MetS foi mais prevalente entre os homens pelo critério do NCEP-ATP III e a obesidade foi o principal fator de risco. Arq Bras Endocrinol Metab. 2010;54(4):390-7

\section{Descritores}

Síndrome metabólica; fatores de risco; coortes de nascimento

\section{INTRODUCTION}

The metabolic syndrome (MetS) is characterized by 1 the presence of a set of cardiovascular risk factors related to resistance to insulin. Prevalence of MetS in- creases with age, and is greater in populations with high prevalence of obesity such as that of the United States, where about $25 \%$ of adults have MetS, ranging from $7 \%$ at age 20 to $44 \%$ at 70 years of age (1). Recently, with 
the increase in prevalence of obesity MetS began to be reported also among children and adolescents (2).

In Brazil, among 12 to 18-year-old girls from public schools in Niteroi, Rio de Janeiro State, the prevalence of MetS according to NCEP-ATPIII was 3.2\% and increased to $21.4 \%$ (95\% CI, 9.86-33.00) among obese subjects (3). In the Ribeirão Preto cohort which used the same criteria prevalence was of $10.7 \%$ among men and $4.8 \%$ among women aged $23-25$ years (4).

The pathogenesis of metabolic syndrome is multifactorial; insulin resistance and obesity are the major risk factors. Physical inactivity, advanced age, hormonal changes, and genetic alterations are known to exacerbate prevalence, but the role of each of these factors may vary according to ethnicity (1).

Prevalence of MetS is higher among low socioeconomic status subjects (5-8) and this association is mediated by differences in diet, physical activity, obesity, and smoking, in addition to the greater deposition of abdominal fat related to high emotional stress (7).

This study was aimed at assessing the prevalence of MetS according to NCEP-ATPIII (9) and IDF (10) criteria in the 1982 Pelotas birth cohort at age 22-23 years, and to evaluate its association with contemporary risk factors.

\section{SUBJECTS AND METHODS}

In 1982, all children born alive in hospitals in the city of Pelotas, Southern Brazil, and whose family lived in the urban area of the city were examined $(n=5,914)$, and mothers were interviewed on socioeconomic, demographic and health-related variables. Weight at birth was measured by the hospital staff using pediatric scales that were calibrated weekly. Gestational age was estimated from the maternal recall of their date of the last menstrual period. The subjects have been followed-up and examined on several occasions and the study methodology has been described elsewhere (11).

Between August 2004 and August 2005, a census was taken in the city in search of residents born in 1982. In addition to the census other tracing strategies were also employed (11). Following the interview, individuals were invited to donate blood which was collected at an outpost set by the research team. Those subjects who did not show up were visited at home. At the time of collection, blood glucose was measured from fingertip blood using an Accu-Check Advantage (Roche) glucose meter which is accepted worldwide in community based diabetes screening $(12,13)$.
Information on the time of the last meal and of blood collection were recorded so that the time elapsed since the last meal could be estimated. Blood samples $(5 \mathrm{~mL})$ were collected from each subject by venous puncture. Colorimetric enzymatic methods were used for determining triglycerides (TG); HDL-cholesterol was measured using an ultrasensitive direct method, both using a Selectra 2 analyzer (Merck).

In the 2004-2005 visits, weight was measured using a portable scale (Seca UNICEF) with $100 \mathrm{~g}$ precision. Weight of clothing was subtracted from the obtained value based on a table of weights of clothing items. Height was assessed using a standardized aluminum anthropometer, with the subject's head in the Frankfurt plan (14).

Abdominal circumference was measured with the subject standing, arms relaxed alongside the body, and the tape measure placed at the level of the natural waist, at the narrowest part of the trunk, between the lowest rib and the iliac crest, at the end of a normal expiration, and without compressing the skin. Measurements were taken using a thin inextensible measure tape, with $0.1 \mathrm{~cm}$ precision. Blood pressure was measured twice, at the beginning and at the end of the interview, using a digital wrist sphygmomanometer (Omron HEM 629). In the present analysis we used the mean value of these two measurements.

The following criteria were used to define metabolic syndrome:

NCEP-ATP III (National Cholesterol Education Program (NCEP)-Adult Treatment Panel III), defined by the presence of at least three of the following factors: abdominal circumference $>102 \mathrm{~cm}$ for men and $>88 \mathrm{~cm}$ for women; triglycerides $\geq 150 \mathrm{mg} / \mathrm{dL}$; blood pressure $\geq 130 / 85 \mathrm{mmHg}$; HDL-cholesterol $<40 \mathrm{mg}$ / $\mathrm{dL}$ for men and $<50 \mathrm{mg} / \mathrm{dL}$ for women; fasting blood glucose $\geq 110 \mathrm{mg} / \mathrm{dL}$ ( $>100 \mathrm{mg} / \mathrm{dL}$ may be used).

International Diabetes Federation (IDF): abdominal circumference $\geq 94 \mathrm{~cm}$ for men and $\geq 80 \mathrm{~cm}$ for women, in addition to two of the following: triglycerides $\geq 150 \mathrm{mg} / \mathrm{dL}$ or under treatment; blood pressure $\geq 130 / 85 \mathrm{mmHg}$ or under treatment; HDL-choleste$\mathrm{rol}<40 \mathrm{mg} / \mathrm{dL}$ for men or $<50 \mathrm{mg} / \mathrm{dL}$ for women or under treatment, fasting blood glucose $\geq 100 \mathrm{mg} / \mathrm{dL}$, or glucose intolerance or diabetes (10).

The following risk factors were evaluated in 20042005:

Obesity: defined as body mass index $\geq 30 \mathrm{~kg} / \mathrm{m}^{2}$.

Overweight: defined as body mass index between 25 and $29.9 \mathrm{~kg} / \mathrm{m}^{2}$. 
Current diet: based on the frequency of intake (daily, weekly and monthly) of 70 food items. Block score was used for assessing the consumption of fiber and fat (15). Low fiber consumption was considered if the amount of fiber in the diet was less than $20 \mathrm{~g}$ a day. Scores of $\mathbf{2 5}$ or higher were considered as high for fat. Carbohydrate $(\mathrm{CH})$ intake, expressed as a percentage of total daily or annual kilocalories was another measure of diet pattern. The percentage of total caloric intake from $\mathrm{CH}$ was categorized as high $(>60 \%)$, middle (50\%-60\%), and low $(<50 \%)$.

Physical activity: leisure time physical activity was evaluated using the International Physical Activity Questionnaire long version (16).Weekly scores of physical activity were estimated by the sum of time of walking and moderate physical activity plus time spent on vigorous activities multiplied by two. Those subjects whose scores were lower than 150 minutes of leisure time were classified as sedentary (17).

Family income: the total income of the family members in the month before the interview (in minimum wages).

Achieved schooling: the highest school grade successfully completed by the subject, divided into 4 categories: $<4$ years, 5 to 8 years, 9 to 11 years, and $\geq 12$ years.

Smoking: those subjects who reported smoking every day in the last week were considered as smokers.

Alcohol consumption: reported as number of doses of alcoholic beverages a day.

Skin color: the subjects self-referred their skin color after hearing the options: white, black, mixed, Asian or indigenous. As the number of subjects was too small in the last two groups, they were mixed in the analysis.

Data analysis was carried out using Stata 9.0 software. In the bivariate analysis, the chi-squared test was used. Since the prevalence of some outcomes was higher than $10 \%$, and in this situation the odds ratio overestimates the prevalence rate, we used the Poisson regression with robust adjustment of the variance in the multivariate analysis to estimate the prevalence ratio (18). Multivariate analysis was done according to a hierarchical model in which socioeconomic and demographic factors determine diet and habits (alcohol intake, smoking, and physical activity) and those habits interfere with current BMI and in the outcome metabolic syndrome. Backward selection of the variables was used; variables with $\mathrm{p} \leq 0.20$ were maintained in the model. Fasting time was not associated with metabolic syndrome, and therefore estimates were not controlled for fasting time.
The study protocol was approved by the Federal University of Pelotas Research Ethics Committee; all subjects provided written consent for the interview and for blood collection and analysis.

\section{RESULTS}

In 2004-2005, we interviewed 4,296 subjects (77.4\% followed-up, including the 282 registered deaths). Of the interviewed subjects, 3,832 provided a blood sample ( $71 \%$ of the original cohort, and $91 \%$ of interviewed subjects). Compared to the original cohort, subjects in the extreme income groups were less likely to be traced (19). We excluded from the metabolic syndrome analysis 103 women who were pregnant at the time of the interview.

Prevalence of metabolic syndrome was $5.9 \%(\mathrm{~N}=$ 213 ) according to NCEP-ATPIII and $6.7 \%(\mathrm{~N}=240)$ according to IDF.

Table 1 shows the characteristics of the studied sample, stratified by sex. Approximately $75 \%$ of the subjects were white; $48 \%$ had between 9 and 11 years of schooling; about one-third of the families had incomes between one and three minimum wages (MW), and other third between 3.1 and 6.0 MW. Prevalence of smoking was $26.0 \%$; low fiber intake was reported by $69 \%$ of subjects, while high fat intake was reported by $64 \%$, the latter being greater among men. Consumption of more than one dose of alcohol per day was reported by $23 \%$ of the sample ( $11 \%$ of women and $34 \%$ of men). Sixtyfour percent of the subjects were considered as sedentary during leisure time. Prevalence of obesity was $8.3 \%$, and of overweight, $21 \%$.

Tables 2 and 3 show the distribution of MetS and its components according to socioeconomic and demographic variables. MetS was more prevalent among men, only according to NCEP criteria, in the lowest family income by IDF, and obese subjects by both criteria. As to MetS components, women showed significantly higher prevalence of abdominal obesity, and of altered HDLcholesterol. Men showed significantly greater prevalence of high blood glucose, triglycerides, and blood pressure. There was significant difference in distribution of MetS components according to skin color: abdominal obesity and systolic blood pressure were more prevalent in nonwhite, and triglycerides among white subjects. Regarding family income, only low HDL- cholesterol and abdominal circumference were higher among the poorest. Finally, regarding the criteria all components of MetS were significantly more frequent among obese subjects. 
Table 1. Characteristics of the population of the 1982 Pelotas Birth Cohort, Brazil, at age 23

\begin{tabular}{|c|c|c|c|}
\hline Variable & $\begin{array}{c}\text { Total } \\
\text { number (\%) }\end{array}$ & $\begin{array}{c}\text { Men } \\
\text { number (\%) }\end{array}$ & $\begin{array}{c}\text { Women } \\
\text { number (\%) }\end{array}$ \\
\hline Sex & $4,296(100)$ & $2,213(51.5)$ & $2,083(48.5)$ \\
\hline Skin color & 4,296 & & \\
\hline White & $3,238(75.4)$ & $1,658(74.9)$ & $1,580(75.9)$ \\
\hline Black or mixed & $908(21.1)$ & $471(21.3)$ & $437(21.0)$ \\
\hline Asian or indigenous & $150(3.5)$ & $84(3.8)$ & $66(3.2)$ \\
\hline Schooling (years) ${ }^{*}$ & 4,296 & & \\
\hline 0 to 4 & $349(8.1)$ & $208(9.4$ & $141(6.8)$ \\
\hline 5 to 8 & $1,208(28.1)$ & $718(32.4)$ & $490(23.5)$ \\
\hline 9 to 11 & $2,070(48.2)$ & $1,011(45.7)$ & $1,059(50.8)$ \\
\hline$\geq 12$ & $669(15.6)$ & $276(12.5)$ & $393(18.9)$ \\
\hline Family income (MW)* & 4,296 & & \\
\hline$\leq 1$ & $298(6.2)$ & $107(4.8)$ & $161(7.7)$ \\
\hline 1.1 to 3.0 & $1,454(33.9)$ & $721(32.6)$ & $733(35.2)$ \\
\hline 3.1 to 6.0 & $1,359(31.6)$ & $714(32.3)$ & $645(31.0)$ \\
\hline$>6.0$ & $1,215(28.3)$ & $671(30.3)$ & $544(26.1)$ \\
\hline \multicolumn{4}{|l|}{ Smokers* } \\
\hline Yes & $1,103(25.7)$ & $611(27.6)$ & $492(23.6)$ \\
\hline No & $3,193(74.3)$ & $1,602(72.4)$ & $1,591(76.4)$ \\
\hline \multicolumn{4}{|l|}{ Alcohol intake* } \\
\hline Zero & $1,391(32.4)$ & $540(24.4)$ & $851(40.8)$ \\
\hline Up to 1 dose/day & $1,916(44.6)$ & $919(41.5)$ & $997(47.9)$ \\
\hline$>1$ dose/day & $989(23.0)$ & $754(34.1)$ & $235(11.3)$ \\
\hline \multicolumn{4}{|l|}{ Fiber intake (Block) } \\
\hline$<20$ g/day & $2,970(69.1)$ & $1,546(69.9)$ & $1,424(68.4)$ \\
\hline$\geq 20$ g/day & $1,326(30.9)$ & $667(30.1)$ & $659(31.6)$ \\
\hline \multicolumn{4}{|l|}{ Fat intake (Block) ${ }^{*}$} \\
\hline Low & $1,546(36.0)$ & $715(32.3)$ & $811(39.9)$ \\
\hline High & $2,750(64.0)$ & $1,498(67.7)$ & $1,252(60.1)$ \\
\hline \multicolumn{4}{|l|}{$\begin{array}{l}\text { Physical activity during } \\
\text { leisure time (minutes) }\end{array}$} \\
\hline Zero & $1,983(46.1)$ & $637(28.8)$ & $1,346(64.6)$ \\
\hline $10-140$ & 784 (18.3) & $454(20.5)$ & $330(15.8)$ \\
\hline 150 and over & $1,529(35.6)$ & $1,122(50.7)$ & 407 (19.6) \\
\hline BMI $\left(\mathrm{kg} / \mathrm{m}^{2}\right)^{*}$ & $N=4,288$ & & \\
\hline$<18.5$ & $257(6.0)$ & $107(4.9)$ & $150(7.2)$ \\
\hline 18.5 to 24.9 & 2,794 (65.2) & $1,424(64.6)$ & $1,370(65.8)$ \\
\hline 25.0 to 29.9 & $881(20.6)$ & 509 (23.1) & $372(17.9)$ \\
\hline$\geq 30$ & $356(8.3)$ & $166(7.5)$ & $190(9.1)$ \\
\hline Metabolic syndrome & $N=3,599$ & & \\
\hline$($ NCEP-ATP III)* & $213(5.9)$ & $132(7.2)$ & $81(4.6)$ \\
\hline $\begin{array}{l}\text { Metabolic syndrome } \\
(\text { (DF)* }\end{array}$ & $240(7.08)$ & $115(6.3)$ & $125(7.1)$ \\
\hline
\end{tabular}

NCEP-ATP III-National Cholesterol Education Program III - IDF-International Diabetes Federation. ${ }^{*} p<0.05 \mathrm{MW}$ : Monthly minimum wage.

Because there was interaction between income and sex $(p=0.002)$, the analyses were stratified according to sex. Table 4 presents crude and adjusted prevalence ratio for MetS based on the NCEP-ATP III criteria, stratified by sex. In the crude analysis, males had a PR of
MetS of 1.56 (95\% CI, 1.19-2.05) according to NCEPATP III, and 0.88 (95\% CI, 0.69-1.13) according to IDF. Among males, skin color, income, and schooling were not associated with MetS. Family income reached the significant threshold for being considered as a confounder and was maintained in the model. None of the behavioral variables (smoking, alcohol intake, diet, and physical activity) was associated with MetS ( $\mathrm{p}>0.05)$, both in crude and adjusted analyses BMI was the only variable associated with MetS among men.

In women, family income and schooling were inversely associated with prevalence of MetS. Smoking, fiber, fat and alcohol intake, and physical activity were not significantly associated with MetS. In the last level, overweight showed a PR of $7.73(\mathrm{p}<0.001)$ and obesity of $40.67(\mathrm{p}<0.001)$ after adjustment for family income and schooling.

The model using MetS as an outcome, as defined by the IDF classification, showed no appreciable differences (Table 5). Among women, higher income and schooling remained as a protective factor, and a higher fiber intake was significantly associated with MetS.

\section{DISCUSSION}

The high prevalence of cardiovascular risk factors among young adults is alarming, and similar results have been described in other studies $(4,20,21)$. In the present study, using NCEP criteria, MetS was more prevalent among men. This is similar to what has been reported in other Latin-American studies with young adults $(4,21,22)$.

Brunner and cols. (5), in 1997, reported a higher risk of MetS among workers of lower socioeconomic class, irrespective of sex, and suggested that this may explain the inequities in distribution of coronary disease in England, a phenomenon also seen in other studies $(23,24)$. Loucks and cols. $(25)$ detected an interaction between sex and socioeconomic level in the same direction as that found in the present study, the prevalence of MetS was positively related to income among men, but negatively related to women. Salaroli and cols. (26) also found higher prevalence among lower socioeconomic women, with no association in men. Differences in prevalence of obesity according to sex and income may explain the interaction found in the present study, given that obesity is more frequent among women of lower income, with no difference in men, in our sample. Indeed, after controlling for obesity the term for signifi- 
Table 2. Distribution of prevalence of metabolic syndrome and its components defined based on NCEP-ATP III, according to sex, skin color, obesity, and socioeconomic indicators in the 1982 Pelotas cohort, at age 23

\begin{tabular}{|c|c|c|c|c|c|c|c|c|c|}
\hline & \multicolumn{2}{|c|}{ Sex } & \multicolumn{2}{|c|}{ Skin color } & \multicolumn{3}{|c|}{ Family income (terciles) } & \multicolumn{2}{|c|}{ Obesity } \\
\hline & Female & Male & White & Nonwhite & 1 & 2 & 3 & Yes & No \\
\hline Blood glucose & 12.9 & $20.9^{*}$ & 16.6 & 18.0 & 18.4 & 15.8 & 16.7 & $24.4^{*}$ & 16.3 \\
\hline HDL-cholesterol & $25.9^{\star}$ & 13.0 & 19.2 & 19.7 & $27.4^{*}$ & 16.9 & 13.4 & $31.7^{*}$ & 18.2 \\
\hline Triglycerides & 10.1 & $22.9^{*}$ & $18.3^{\star}$ & 12.0 & 14.8 & 17.2 & 18.2 & $39.9^{*}$ & 14.6 \\
\hline Abdominal circumference & $10.9^{*}$ & 4.2 & 6.7 & $9.4^{8}$ & $9.8^{*}$ & 7.7 & 4.7 & $67.7^{\star}$ & 2.0 \\
\hline Systolic blood pressure & 13.2 & $35.5^{\star}$ & 24.1 & $27.8^{8}$ & 23.3 & 26.8 & 24.8 & $47.7^{\star}$ & 23.0 \\
\hline Metabolic syndrome & 4.6 & $7.2^{\star}$ & 5.9 & 6.1 & 6.3 & 5.9 & 5.6 & $39.3^{*}$ & 2.9 \\
\hline
\end{tabular}

${ }^{*} p \leq 0.001 ;{ }^{*} p \leq 0.05$

Table 3. Distribution of prevalence of metabolic syndrome and its components defined based on IDF, according to sex, skin color, obesity, and socioeconomic indicators in the 1982 Pelotas cohort, at age 23

\begin{tabular}{|c|c|c|c|c|c|c|c|c|c|}
\hline & \multicolumn{2}{|c|}{ Sex } & \multicolumn{2}{|c|}{ Skin color } & \multicolumn{3}{|c|}{ Family income (terciles) } & \multicolumn{2}{|c|}{ Obesity } \\
\hline & Female & Male & White & Nonwhite & 1 & 2 & 3 & Yes & No \\
\hline Blood glucose & 30.1 & $43.2^{*}$ & 36.4 & 37.5 & 38.4 & 35.8 & 35.9 & $46.2^{*}$ & 35.8 \\
\hline HDL-cholesterol & $25.9^{*}$ & 13.0 & 19.2 & 19.7 & $27.4^{*}$ & 16.9 & 13.4 & $31.7^{\star}$ & 18.2 \\
\hline Triglycerides & 10.1 & $22.9^{*}$ & $18.3^{*}$ & 12.0 & 14.8 & 17.2 & 18.2 & $39.9^{*}$ & 14.6 \\
\hline Abdominal circumference & $24.5^{\star}$ & 10.2 & 16.3 & $19.0^{\&}$ & $19.7^{*}$ & 18.6 & 12.6 & $94.1^{*}$ & 10.1 \\
\hline Systolic blood pressure & 13.2 & $35.5^{*}$ & 24.1 & $27.8^{\&}$ & 23.3 & 26.8 & 24.8 & $47.7^{\star}$ & 23.0 \\
\hline Metabolic syndrome & 7.1 & 6.3 & 6.5 & 7.1 & $7.8 \&$ & 6.9 & 5.3 & $51.7^{\star}$ & 2.6 \\
\hline
\end{tabular}

${ }^{*} p \leq 0.001 ;{ }^{\&} p \leq 0.01$.

cance of interaction was reduced $(p=0.11)$. Another possible explanation would be the higher parity found among women of lower socioeconomic level, since higher parity has been associated with greater abdominal obesity (27).

Contemporary diet, smoking, alcohol use, and physical activity were not associated with MetS, contrary to what has been reported in other studies (28-31), with the exception of higher risk in those women with higher fiber consumption. A possible explanation for these results is the fact that ours is a young population, who may not have been exposed to these factors long enough to have had an effect on the components of MetS. Non-differential information bias is another potential explanation for the lack of an association, given that diet was measured indirectly. Moreover, reverse causality may have minimized the impact of physical activity, with more obese individuals having been more physically active. On the other hand, even within a small sample in which physical activity was evaluated during adolescence $(\mathrm{N}=227$, data not shown), this variable was not associated with MetS, thus suggesting that reverse causality is not the most plausible explanation for this lack of association.
One of the weaknesses of the present study is that blood collection did not follow a period of prolonged fasting: on average, subjects had eaten their last meal 3.7 hours before blood collection, with a median period of 3 hours. In our sample, there was no association between duration of fasting and altered HDL ( $\mathrm{p}$ $=0.33)$ but this variable was associated with altered blood glucose levels $(\mathrm{p}<0.001)$ and triglycerides $(\mathrm{p}<$ 0.001 ). However, the prevalence of metabolic syndrome was not associated with time of fasting $(\mathrm{p}=0.13)$. Therefore, we do not believe that our findings were biased by fasting time.

Another limitation of the study is the fact we used random capillary blood glucose (RCBG), however this is the most convenient way to reach large numbers of people, and in a publication evaluating the screening tests for type 2 diabetes, the World Health Organization (WHO) found that studies have mostly used RCBG measured with a blood glucose meter and reported a sensitivity between $68 \%-74 \%$ and specificity ranging from $66 \%-77 \%$, depending on age, with a cut point of $5.6 \mathrm{mmol}(100 \mathrm{mg} / \mathrm{dL})$. The same report of the WHO says that although the accuracy of a glucose meter has been questioned, these problems are "not 
Table 4. Poisson regression of RR for metabolic syndrome according to NCEP-ATP III criteria; crude and adjusted for demographic, socioeconomic, and behavioral factors, stratified by sex in the 1982 Pelotas cohort at age 23

\begin{tabular}{|c|c|c|c|c|}
\hline & \multicolumn{2}{|c|}{ Men } & \multicolumn{2}{|c|}{ Women } \\
\hline & Crude & Adjusted & Crude & Adjusted \\
\hline Variable & RR & RR & RR & $\mathrm{RR}$ \\
\hline $\begin{array}{l}\text { Skin color } \\
\text { White } \\
\text { Nonwhite }\end{array}$ & $\begin{array}{c}p=0.98 \\
1.00 \\
0.99 \\
(0.68-1.45)\end{array}$ & $\begin{array}{c}p=0.98^{1} \\
1.00 \\
0.99 \\
(0.68-1.45)\end{array}$ & $\begin{array}{c}p=0.64 \\
1.00 \\
1.12 \\
(0.69-1.81)\end{array}$ & $\begin{array}{c}p=0.67^{1} \\
1.00 \\
0.90 \\
(0.56-1.45)\end{array}$ \\
\hline $\begin{array}{l}\text { Family income } \\
\text { (terciles) } \\
\text { Lower } \\
\text { Middle } \\
\text { Upper }\end{array}$ & $\begin{array}{c}p=0.18 \\
1.00 \\
1.16 \\
(0.76-1.79) \\
1.32 \\
(0.87-2.00)\end{array}$ & $\begin{array}{c}p=0.08^{1} \\
1.00 \\
1.24 \\
(0.79-1.95) \\
1.54 \\
(0.95-2.48)\end{array}$ & $\begin{array}{c}p=0.001 \\
1.00 \\
0.69 \\
(0.43-1.11) \\
0.38 \\
(0.21-0.70)\end{array}$ & $\begin{array}{c}p=0.02^{1} \\
1.00 \\
0.78 \\
(0.48-1.25) \\
0.52 \\
(0.28-0.96)\end{array}$ \\
\hline $\begin{array}{l}\text { Schooling (years) } \\
0 \text { to } 4 \\
5 \text { to } 8 \\
9 \text { to } 11 \\
\geq 12\end{array}$ & $\begin{array}{c}p=0.48 \\
0.90 \\
(0.45-1.83) \\
1.01 \\
(0.61-1.70) \\
0.71 \\
(0.42-1.19) \\
1.00\end{array}$ & $\begin{array}{c}p=0.171 \\
1.20 \\
(0.55-2.59) \\
1.23 \\
(0.70-2.17) \\
0.78 \\
(0.46-1.32) \\
1.00\end{array}$ & $\begin{array}{c}p=0.001 \\
3.31 \\
(1.13-9.63) \\
3.60 \\
(1.51-8.59) \\
2.38 \\
(1.027-5.55) \\
1.00\end{array}$ & $\begin{array}{c}p=0.061 \\
2.26 \\
(0.77-6.61) \\
2.53 \\
(1.03-6.21) \\
1.94 \\
(0.82-4.58) \\
1.00\end{array}$ \\
\hline Smoking & $\begin{array}{c}p=0.42 \\
0.85 \\
(0.58-1.25)\end{array}$ & $\begin{array}{c}p=0.24^{2} \\
0.77 \\
(0.50-1.19)\end{array}$ & $\begin{array}{c}p=0.94 \\
0.98 \\
(0.59-1.62)\end{array}$ & $\begin{array}{c}p=0.37^{2} \\
0.79 \\
(0.47-1.33)\end{array}$ \\
\hline $\begin{array}{l}\text { Alcohol intake } \\
\text { Zero } \\
\text { Up to } 1 \text { dose/day } \\
>1 \text { dose/day }\end{array}$ & $\begin{array}{c}p=0.67 \\
1.00 \\
0.99 \\
(0.65-1.52) \\
1.09 \\
(0.71-1.69)\end{array}$ & $\begin{array}{c}p=0.56^{2} \\
1.00 \\
1.04 \\
(0.67-1.60) \\
1.14 \\
(0.72-1.83)\end{array}$ & $\begin{array}{c}p=0.29 \\
1.00 \\
0.96 \\
(0.62-1.50) \\
0.59 \\
(0.25-1.38)\end{array}$ & $\begin{array}{c}p=0.80^{2} \\
1.00 \\
1.13 \\
(0.72-1.78) \\
0.73 \\
(0.31-1.73)\end{array}$ \\
\hline Higher fiber intake & $\begin{array}{c}p=0.10 \\
1.33 \\
(0.94-1.86)\end{array}$ & $\begin{array}{c}p=0.09^{2} \\
1.35 \\
(0.950-1.92)\end{array}$ & $\begin{array}{c}p=0.86 \\
1.04 \\
(0.66-1.64)\end{array}$ & $\begin{array}{c}p=0.75^{2} \\
1.06 \\
(0.67-1.68)\end{array}$ \\
\hline High fat intake & $\begin{array}{c}p=0.99 \\
1.00 \\
(0.70-1.42)\end{array}$ & $\begin{array}{c}p=0.69^{2} \\
0.93 \\
(0.64-1.34)\end{array}$ & $\begin{array}{c}p=0.13 \\
0.72 \\
(0.47-1.10)\end{array}$ & $\begin{array}{c}p=0.44^{2} \\
0.85 \\
(0.54-1.33)\end{array}$ \\
\hline $\begin{array}{l}\text { Physical activity } \\
\text { during leisure time } \\
\text { (minutes) } \\
\text { Zero } \\
10-140 \\
150 \text { or more }\end{array}$ & $\begin{array}{c}p=0.34 \\
1.18 \\
(0.80-1.73) \\
1.31 \\
(0.87-1.98) \\
1.00\end{array}$ & $\begin{array}{c}p=0.22^{2} \\
1.25 \\
(0.84-1.87) \\
1.38 \\
(0.91-2.10) \\
1.00\end{array}$ & $\begin{array}{c}p=0.32 \\
1.52 \\
(0.80-2.88) \\
1.91 \\
(0.91-4.02) \\
1.00\end{array}$ & $\begin{array}{c}p=0.73^{2} \\
1.24 \\
(0.64-2.39) \\
1.56 \\
(0.72-3.35) \\
1.00\end{array}$ \\
\hline $\begin{array}{l}\text { BMI }\left(\mathrm{kg} / \mathrm{m}^{2}\right) \\
\text { Normal } \\
\text { Overweight }\end{array}$ & $\begin{array}{c}p<0.001 \\
1.00 \\
3.06 \\
(1.90-4.95)\end{array}$ & $\begin{array}{c}p<0.001^{3} \\
1.00 \\
3.14 \\
(1.97-5.00)\end{array}$ & $\begin{array}{c}p<0.001 \\
1.00 \\
7.99 \\
(3.72-17.19)\end{array}$ & $\begin{array}{c}p<0.001^{4} \\
1.00 \\
7.73 \\
(3.65-16.38)\end{array}$ \\
\hline Obese & $\begin{array}{c}17.87 \\
(11.75-27.17)\end{array}$ & $\begin{array}{c}17.41 \\
(11.85-25.60)\end{array}$ & $\begin{array}{c}42.65 \\
(21.68-83.92)\end{array}$ & $\begin{array}{c}40.67 \\
(20.85-79.33)\end{array}$ \\
\hline
\end{tabular}

${ }^{1}$ : adjusted for variables in the first level (skin color, schooling and family income); ${ }^{2}$ : adjusted for schooling, family income and variables of the second level (smoking, alcohol intake, higher fiber and fat intake and physical activity; ${ }^{3}$ : Adjusted for schooling, family income, higher fiber intake

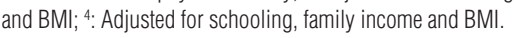

Table 5. Poisson regression of RR for metabolic syndrome according to IDF criteria; crude and adjusted for demographic, socioeconomic, and behavioral factors, stratified by sex in the 1982 Pelotas cohort at age 23

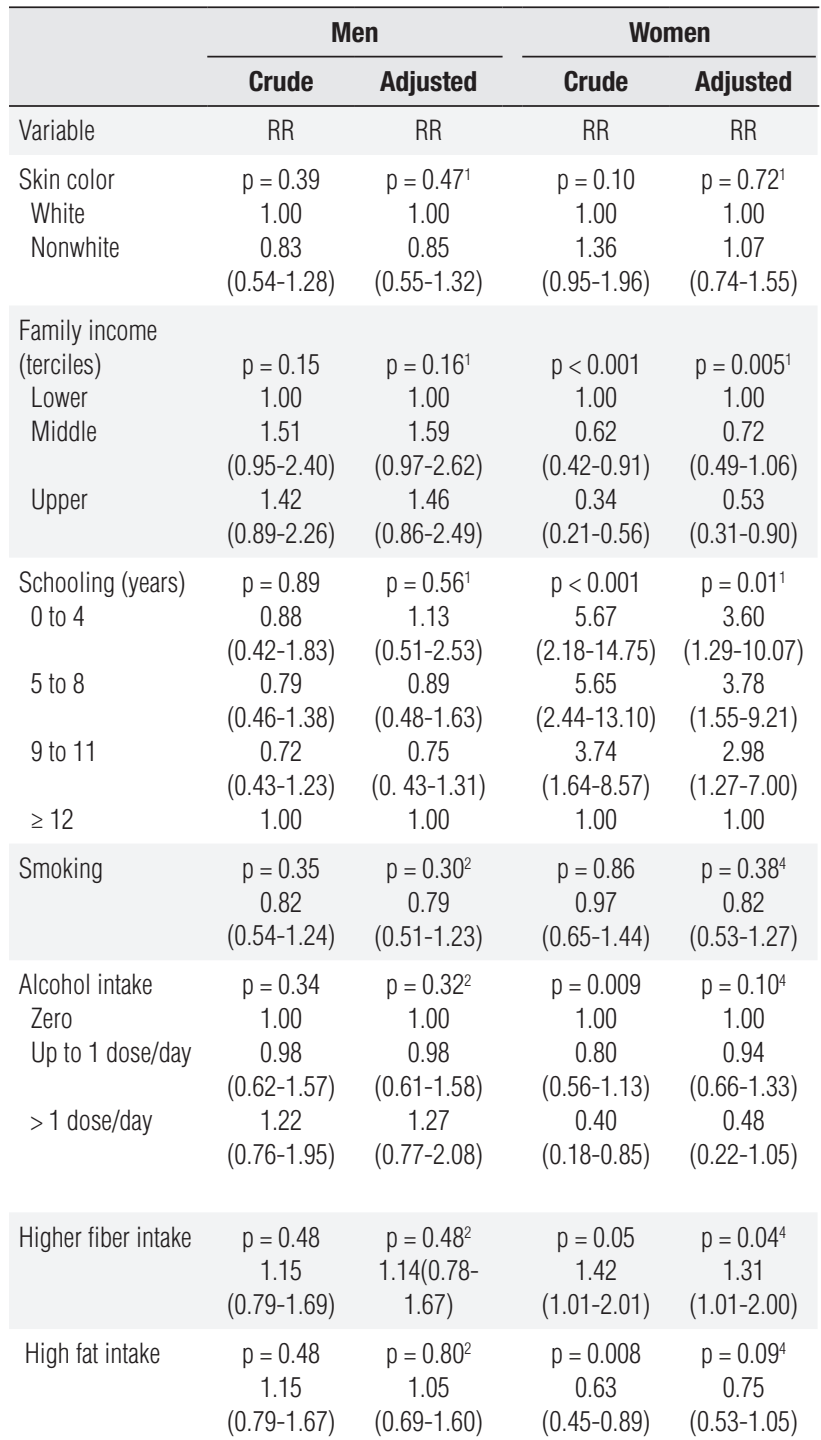

\begin{tabular}{lcccc}
$\begin{array}{l}\text { Physical activity } \\
\text { during leisure time } \\
\text { (minutes) }\end{array}$ & $\mathrm{p}=0.33$ & $\mathrm{p}=0.17^{2}$ & $\mathrm{p}=0.68$ & $\mathrm{p}=0.18^{4}$ \\
Zero & 1.20 & 1.31 & 0.96 & 0.76 \\
& $(0.79-1.81)$ & $(0.85-2.00)$ & $(0.62-1.48)$ & $(0.50-1.17)$ \\
$10-140$ & 1.33 & 1.41 & 1.19 & 0.94 \\
& $(0.85-2.07)$ & $(0.90-2.20)$ & $(0.69-2.04)$ & $(0.54-1.62)$ \\
150 or more & 1.00 & 1.00 & 1.00 & 1.00 \\
BMl $\left(\mathrm{kg} / \mathrm{m}^{2}\right)$ & $\mathrm{p}<0.001$ & $\mathrm{p}<0.0001^{3}$ & $\mathrm{p}<0.001$ & $\mathrm{p}<0.001^{5}$ \\
Normal & 1.00 & 1.00 & 1.00 & 1.00 \\
Overweight & 35.69 & 35.76 & 18.74 & 17.67 \\
& $(8.47-150.45)$ & $(8.8-150.75)$ & $(9.86-35.63)$ & $(9.30-33.56)$ \\
Obese & 403.68 & 406.98 & 48.47 & 42.53 \\
& $(100.46-$ & $(101.26-$ & $(26.14-$ & $(22.67-$ \\
& $1622.10)$ & $1635.74)$ & $89.87)$ & $79.80)$ \\
\hline
\end{tabular}

1: adjusted for variables in the first level: skin color, family income, and schooling: 2 : adjusted for second level variables: alcohol intake, smoking, low fiber, high fat intake, and leisure time physical activity; ${ }^{3}$ : adjusted for smoking, alcohol intake, physical activity and $\mathrm{BMl} ;{ }^{4}$ : adjusted for family income, schooling and second level variables; ${ }^{5}$ : adjusted for family income, schooling, higher fat, and fiber intake, physical activity during leisure time and BMI. 
necessarily insurmountable and the final decision about their use will depend on resources and related practical considerations" (13). The mean blood glucose level in this study was $97.3 \pm 15.1 \mathrm{mg} / \mathrm{dL}$ and the median was $95.0 \mathrm{mg} / \mathrm{dL}$, similar to a study performed in Vitória, ES, with mean fasting blood glucose of $98.9 \pm 19.9$ and $95.1 \pm 13.7$ in men and women without MetS, respectively (26).

Despite this being a young population, obesity was strongly associated with risk of MetS. Countless studies have detected associations between obesity and MetS $(32,33)$; in the Bogalusa Heart Study, childhood obesity was the strongest predictor of MetS in adult life (34) as well as the most important risk factor for cardiovascular disease $(35,36)$, which remains as the major cause of death worldwide, especially in developing countries.

The findings in the present study confirm the need for early intervention against obesity so as to prevent its impact on cardiovascular risk factors. It is necessary that health workers be alerted as to the need for measuring blood pressure, BMI, and abdominal circumference, in addition to metabolic parameters, especially among the obese, at earlier ages. It will also be necessary that health workers orient patients as to leading a healthy lifestyle, by means of adequate nutrition and physical activity. This may help delay or prevent the progression of MetS to diabetes mellitus, cardiovascular disease, and other complications that can affect the survival of future generations.

This article is based on data from the study "Pelotas Birth Cohort, 1982" conducted by a Postgraduate Program in Epidemiology at Universidade Federal de Pelotas. The 1982 Birth Cohort study is currently supported by the Wellcome Trust initiative entitled "Major Awards for Latin America on Health Consequences of Population Change". Previous phases of the study were supported by the International Development Research Center, The World Health Organization, Overseas Development Administration, European Union, National Support Program for Centers of Excellence (PRONEX), the Brazilian National Research Council (CNPq) and Brazilian Ministry of Health.

Disclosure: no potential conflict of interest relevant to this article was reported.

\section{REFERENCES}

1. Eckel RH, Grundy SM, Zimmet PZ. The metabolic syndrome. Lancet. 2005;365:1415-28.
2. Boney CM, Verma A, Tucker R, Vohr BR. Metabolic syndrome in childhood: association with birth weight, maternal obesity, and gestational diabetes mellitus. Pediatrics. 2005;115:e290-6.

3. Alvarez MM, Vieira AC, Moura AS, da Veiga GV. Insulin resistance in Brazilian adolescent girls: association with overweight and metabolic disorders. Diabetes Res Clin Pract. 2006;74:183-8.

4. Barbieri MA, Bettiol H, Silva AA, Cardoso VC, Simoes VM, Gutierrez MR, et al. Health in early adulthood: the contribution of the 1978/79 Ribeirao Preto birth cohort. Braz J Med Biol Res. 2006;39:1041-55.

5. Brunner EJ, Marmot MG, Nanchahal K, Shipley MJ, Stansfeld SA, Juneja $M$, et al. Social inequality in coronary risk: central obesity and the metabolic syndrome. Evidence from the Whitehall II study. Diabetologia. 1997;40:1341-9.

6. Hidvegi T, Hetyesi K, Biro L, Jermendy G. Education level and clustering of clinical characteristics of metabolic syndrome. Diabetes Care. 2001;24:2013-5.

7. Rosmond R, Bjorntorp P. Occupational status, cortisol secretory pattern, and visceral obesity in middle-aged men. Obes Res. 2000;8:445-50.

8. ParkYW, Zhu S, Palaniappan L, Heshka S, Carnethon MR, Heymsfield SB. The metabolic syndrome: prevalence and associated risk factor findings in the US population from the Third National Health and Nutrition Examination Survey, 1988-1994. Arch Intern Med. 2003;163:427-36.

9. Executive Summary of The Third Report of The National Cholesterol Education Program (NCEP) Expert Panel on Detection, Evaluation, and Treatment of High Blood Cholesterol in Adults (Adult Treatment Panel III). JAMA. 2001;285:2486-97.

10. Alberti KG, Zimmet P, Shaw J. The metabolic syndrome - a new worldwide definition. Lancet. 2005;366:1059-62.

11. Barros FC, Victora CG, Horta BL, Gigante DP. [Methodology of the Pelotas birth cohort study from 1982 to 2004-5, Southern Brazil]. Rev Saude Publica. 2008;42 Suppl 2:7-15.

12. Somannavar S, Ganesan A, Deepa M, Datta M, Mohan V. Random capillary blood glucose cut points for diabetes and pre-diabetes derived from community-based opportunistic screening in India. Diabetes Care. 2009;32:641-3.

13. Screening forType 2 Diabetes - Report of a World Health Organization and International Diabetes Federation meeting. 2003.

14. Physical status: the use and interpretation of anthropometry. Report of a WHO Expert Committee. World Health Organ Tech Rep Ser. 1995;854:1-452.

15. Thompson FE, Byers T. Dietary assessment resource manual. J Nutr. 1994;124:2245S-317S.

16. Craig $C L$, Marshall $A L$, Sjostrom $M$, Bauman $A E$, Booth $M L$, Ainsworth $\mathrm{BE}$, et al. International physical activity questionnaire: 12-country reliability and validity. Med Sci Sports Exerc. 2003;35:1381-95.

17. Haskell WL, Lee IM, Pate RR, Powell KE, Blair SN, Franklin BA, et al. Physical activity and public health: updated recommendation for adults from the American College of Sports Medicine and the American Heart Association. Med Sci Sports Exerc. 2007;39:1423-34.

18. Barros AJ, Hirakata VN. Alternatives for logistic regression in cross-sectional studies: an empirical comparison of models that directly estimate the prevalence ratio. BMC Med Res Methodol. 2003;3:21.

19. Victora CG, Barros FC. Cohort profile: the 1982 Pelotas (Brazil) birth cohort study. Int J Epidemiol. 2006;35:237-42.

20. Ford ES, GilesWH, DietzWH. Prevalence of the metabolic syndrome among US adults: findings from the third National Health and Nutrition Examination Survey. JAMA. 2002;287:356-9.

21. Bustos $P$, Amigo $H$, Arteaga $A$, Acosta AM, Rona RJ. [Risk factors of cardiovascular disease among young adults]. Rev Med Chil. 2003;131:973-80. 
22. Florez H, Silva E, Fernandez V, Ryder E, Sulbaran T, Campos G, et al. Prevalence and risk factors associated with the metabolic syndrome and dyslipidemia in White, Black, Amerindian and Mixed Hispanics in Zulia State, Venezuela. Diabetes Res Clin Pract. 2005;69:63-77.

23. Langenberg C, Kuh D, Wadsworth ME, Brunner E, Hardy R. Social circumstances and education: life course origins of social inequalities in metabolic risk in a prospective national birth cohort. Am J Public Health. 2006;96:2216-21.

24. Silventoinen K, Pankow J, Jousilahti P, Hu G, Tuomilehto J. Educational inequalities in the metabolic syndrome and coronary heart disease among middle-aged men and women. Int J Epidemiol. 2005;34:327-34.

25. Loucks EB, Magnusson KT, Cook S, Rehkopf DH, Ford ES, Berkman LF. Socioeconomic position and the metabolic syndrome in early, middle, and late life: evidence from NHANES 1999-2002. Ann Epidemiol. 2007;17:782-90.

26. Salaroli LB, Barbosa GC, Mill JG, Molina MC. [Prevalence of metabolic syndrome in population-based study, Vitoria, ES-Brazil]. Arq Bras Endocrinol Metabol. 2007;51:1143-52.

27. Castanheira M, Olinto MT, Gigante DP. [Socio-demographic and lifestyle factors associated with abdominal fat distribution in adults: a population-based survey in Southern Brazil]. Cad Saude Publica. 2003;19 Suppl 1:S55-65.

28. McKeown NM, Meigs JB, Liu S, Saltzman E, Wilson PW, Jacques PF. Carbohydrate nutrition, insulin resistance, and the prevalence of the metabolic syndrome in the Framingham Offspring Cohort. Diabetes Care. 2004;27:538-46.

29. Lee WY, Jung CH, Park JS, Rhee EJ, Kim SW. Effects of smoking, alcohol, exercise, education, and family history on the metabolic syndrome as defined by the ATP III. Diabetes Res Clin Pract. 2005; 67:70-7.

30. Djousse L, Arnett DK, Eckfeldt JH, Province MA, Singer MR, Ellison RC. Alcohol consumption and metabolic syndrome: does the type of beverage matter? Obes Res. 2004;12:1375-85.

31. SteemburgoT, Dall'Alba V, Gross JL, Azevedo MJ. [Dietary factors and metabolic syndrome]. Arq Bras Endocrinol Metabol. 2007; 51:1425-33.

32. Fernandez ML.The metabolic syndrome. Nutr Rev. 2007;65:S30-4.

33. Meigs JB. Epidemiology of the metabolic syndrome, 2002. Am J Manag Care. 2002;8:S283-92; quiz S93-6.

34. Srinivasan SR, Myers L, Berenson GS. Predictability of childhood adiposity and insulin for developing insulin resistance syndrome (syndrome X) in young adulthood: the Bogalusa Heart Study. Diabetes. 2002;51:204-9.

35. Haffner SM, Despres J-P, Balkau B, et al. Waist circumference and body mass index are both independently associated with cardiovascular disease: The International Day for the Evaluation of Abdominal Obesity (IDEA) survey. J Am Coll Cardiol. 2006;47(4 suppl A):358A.

36. Baker JL, Olsen LW, Sorensen TI. Childhood body-mass index and the risk of coronary heart disease in adulthood. $\mathrm{N}$ Engl $\mathrm{J}$ Med. 2007;357:2329-37. 